KLAUZULA PRZECIWKO UNIKANIU OPODATKOWANIA NIE OZNACZA ZAKAZU OPTYMALIZACJI PODATKOWEJ GLOSA KRYTYCZNA DO ODMOWY WYDANIA OPINII ZABEZPIECZAJĄCEJ Z DNIA 28 MAJA 2020 R. $\mathrm{DKP}_{3.8011 .8 .2019}$

\begin{abstract}
Streszczenie. 28 maja 2020 r. Szef KAS odmówił wydania opinii zabezpieczającej dotyczącej możliwości rozpoznania przez podatnika straty na sprzedaży podmiotowi powiązanemu akcji spółki zależnej, których wartość znacząco spadła. Organ argumentował m.in., że dopuszczenie rozpoznania straty podatkowej na takiej sprzedaży pozostawałoby sprzeczne z przedmiotem lub celem ustawy podatkowej. Uznał on, że sprzeczność ta wynika z faktu „żonglowania” przez podatnika aktywami w ramach grupy kapitałowej w celu aktywacji kosztów podatkowych. W niniejszej glosie krytycznej autor wskazuje, że zasadność rozstrzygnięcia Szefa KAS wydanego w analizowanej sprawie budzi wątpliwości. Podważa on w szczególności argumentację organu wskazującą, że rozpoznanie ekonomicznej straty w ramach transakcji z podmiotem powiązanym pozostaje sprzeczne z przedmiotem lub celem ustawy podatkowej lub jej przepisu.
\end{abstract}

Słowa kluczowe: klauzula przeciwko unikaniu opodatkowania, GAAR, art. 119a Ordynacji podatkowej, korzyść podatkowa, sprzeczność z przedmiotem lub celem ustawy podatkowej lub jej przepisu, sztuczność, działanie w celu osiągnięcia korzyści podatkowej, podmioty powiązane

* Doktor nauk prawnych, doradca podatkowy w PwC, e-mail: kontakt@mikolajkondej.pl 
28 maja 2020 r. Szef KAS odmówił wydania opinii zabezpieczającej dotyczącej możliwości rozpoznania przez spółkę straty na sprzedaży akcji spółki zależnej na rzecz powiązanej spółki kapitałowej․ Tym samym stwierdził on, że do wskazanej transakcji może znaleźć zastosowanie klauzula ogólna przeciwko unikaniu opodatkowania.

W stanie faktycznym analizowanej sprawy polska spółka kapitałowa (dalej: wnioskodawca) objęła akcje spółki, która realizowała inwestycje poza granicami kraju (dalej: spółka zależna). Inwestycja ta okazał się jednak nietrafiona. Wartość akcji spółki zależnej spadła do około 8\% kwoty, za którą wnioskodawca je nabył.

W 2017 r. wnioskodawca zbył akcje spółki zależnej, realizując stratę. Sprzedaż miała miejsce na rzecz spółki siostry wnioskodawcy. Była to spółka, którą spółka matka kupiła od kancelarii prawnej, a następnie dokapitalizowała.

Przed restrukturyzacją spółka sprzedająca pełniła w ramach grupy funkcje zarządcze wobec spółki zależnej i innych podmiotów. Funkcje te przeniesiono równocześnie ze zbyciem wskazanej spółki. Do kupującego, w związku z transakcją, przeszło kilku pracowników, którzy je realizowali.

Rozpatrując, czy transakcja jest objęta klauzulą, Szef KAS uznał, że głównym celem działania wnioskodawcy była chęć realizacji straty. W szczególności zakwestionował istotność wskazywanego przez podatnika celu realizacji czynności w postaci uzyskania przez niego środków pieniężnych na realizację bieżących zobowiązań spółki. Wskazał bowiem, że skoro spółka matka mogła dokapitalizować nabywcę będącego spółką siostrą wnioskodawcy, umożliwiając mu zakup akcji, to wskazany cel mógł zostać zrealizowany również poprzez bezpośrednie dokapitalizowanie wnioskodawcy.

Szef KAS wskazał, że na motywacje podatkowe wskazuje też fakt, iż restrukturyzacja pozwoliła na optymalizację podatkową rozliczeń podatkowych sprzedawanej spółki zależnej wobec administracji skarbowej kraju jej siedziby. Organ doszedł do przekonania, że jeżeli restrukturyzacja była motywowana m.in. zagranicznymi względami fiskalnymi, należy założyć, iż przy podejmowaniu decyzji o jej realizacji uwzględniono także powstanie straty w podatku dochodowym od osób prawnych w Polsce.

1 Informacja dotycząca odmowy wydania opinii zabezpieczającej z dnia 28 maja 2020 r. DKP3.8011.8.2019; SIP: 190158/K. 
Szef KAS uznał ponadto, że sposób działania podatnika był sztuczny. Wskazał, że przejście części pracowników wnioskodawcy do nabywcy wskazuje, iż z ekonomicznego punktu widzenia doszło do transakcji zbycia zorganizowanej części przedsiębiorstwa, która jedynie dla celów podatkowych została podzielona na dwie części: sprzedaż akcji / przeniesienie pracowników. Wskazał on również, że cała operacja mogła zostać dokonana w prostszy sposób, poprzez przeprowadzenie podziału wnioskodawcy przez wydzielenie. Uwzględniwszy powyższe, Szef KAS stwierdził, że gdyby nie chęć osiągnięcia korzyści podatkowej, wnioskodawca oraz grupa kapitałowa przeprowadziliby restrukturyzację w inny sposób, co wskazuje na sztuczność przyjętego sposobu działania.

Szef KAS stwierdził też, że osiągnięta przez podatnika korzyść podatkowa pozostaje sprzeczna z przedmiotem i celem art. 16 ust. 1 pkt 8 ustawy o CIT $^{2}$. Wskazał on, że chociaż doszło do zbycia akcji, miało ono miejsce w ramach grupy kapitałowej. W ten sposób w grupie tej została wygenerowana tarcza podatkowa, która pozwala na obniżenie zobowiązań podatkowych płaconych przez spółki wchodzące w jej skład bez utraty aktywów posiadanych przez grupę. Podniósł on, że w istocie doszło jedynie do przeniesienia akcji „, kieszeni od kieszeni” w ramach grupy kapitałowej. Zdaniem Szefa KAS skoro spółka zależna nie opuściła, w wyniku zbycia udziałów, grupy, to potrącenie kosztów uzyskania przychodów na tym etapie jest sprzeczne z celem i przedmiotem ustawy podatkowej.

Korzyść została uznana za sprzeczną z przedmiotem i celem ustawy podatkowej również $\mathrm{z}$ tego powodu, że transfer aktywów do kupującego mógł zostać dokonany na wiele innych sposobów, a sprzedaż została wybrana ze względu na to, iż pozwoliła rozpoznać stratę. Szef KAS wywiódł więc sprzeczność korzyści podatkowej ze sztuczności działania podatnika. Wskazał, że „ «żonglowanie» aktywami w ramach wielu posiadanych spółek i «aktywacja» możliwości potrącenia kosztów uzyskania przychodów nie świadczy o korzystaniu przez Wnioskodawcę z uprawnienia wynikającego z art. 16 ust. 1 pkt 8 ustawy o CIT w sposób zgodny z celem i przedmiotem tego przepisu".

W efekcie powyższych konstatacji Szef KAS doszedł do wniosku, że rozliczenie straty na sprzedaży akcji było unikaniem opodatkowania, objętym przepisami klauzuli przeciwko unikaniu opodatkowania.

${ }^{2}$ Ustawa z dnia 15 lutego 1992 r. o podatku dochodowym od osób prawnych (Dz.U. 2020, poz. 1406). 
2. WARUNKI ZASTOSOWANIA KLAUZULI W 2017 R.

Przechodząc do oceny orzeczenia, na wstępie należy stwierdzić, że odmowa wydania opinii zabezpieczającej została wydana w odniesieniu do stanu faktycznego, który miał miejsce w 2017 r. Do analizowanej sprawy znajdują więc zastosowanie przepisy klauzuli przeciwko unikaniu opodatkowania w brzmieniu ówcześnie obowiązującym, bez uwzględnienia nowelizacji, która weszła w życie 1 stycznia 2019 r., w istotny sposób zmieniając zakres zastosowania klauzuli³.

W efekcie dla stwierdzenia możliwości zastosowania klauzuli do sprzedaży akcji wymagane pozostawało łączne stwierdzenie:

1) że czynność została dokonana przede wszystkim w celu osiągnięcia korzyści podatkowej („warunek głównego celu”),

2) że korzyść podatkowa pozostaje $w$ danych okolicznościach sprzeczna $\mathrm{z}$ przedmiotem i celem przepisu ustawy podatkowej („warunek sprzeczności”),

3) że sposób działania podatnika był sztuczny, tzn. że w istniejących okolicznościach ten sposób nie zostałby zastosowany przez podmiot działający rozsądnie i kierujący się zgodnymi z prawem celami innymi niż osiągnięcie korzyści podatkowej sprzecznej z przedmiotem i celem przepisu ustawy podatkowej („warunek sztuczności”).

3. WARUNek GeÓWNEgo Celu

W pierwszej kolejności w glosie zostanie przeanalizowany warunek głównego celu. Zgodnie z przepisami obowiązującymi w 2017 r. warunkiem zastosowania klauzuli pozostawało to, by czynność była dokonana przede wszystkim w celu osiągnięcia korzyści podatkowej.

W informacji szefa KAS zawarto informacje, że zdaniem podatnika sprzedaż akcji służyła:

1) zapewnieniu klarownego rozdzielenia funkcji pomiędzy spółkami z grupy kapitałowej,

2) istotnemu zmniejszeniu ryzyka gospodarczego wnioskodawcy poprzez przeniesienie $\mathrm{z}$ wnioskodawcy na nabywcę pakietu akcji udzielonych gwarancji związanych z działalnością spółki zależnej,

3 Zmiany te omawiam w innym artykule: M. Kondej, Zmiany w klauzuli ogólnej przeciwko unikaniu opodatkowania wchodzace w życie w 2019 r., „Praktyka Podatkowa” 2018, nr 1, s. 4-19. 
3) dywersyfikacji poziomu i profilu ryzyka umożliwiającego efektywne zarządzanie ryzykiem operacyjnym i inwestycyjnym,

4) oddzieleniu funkcji zarządzania holdingowego i zarządzania operacyjnego,

5) zwiększeniu możliwości finansowania zewnętrznego nowych projektów, zwiększeniu potencjału oraz zmniejszeniu ograniczeń w stosowaniu zabezpieczeń finansowych,

6) uzyskaniu środków pieniężnych pozwalających na regulowanie bieżących zobowiązań.

Odnosząc się do powyższego, Szef KAS „, z celów gospodarczo relewantnych dla dokonania czynności odpłatnego zbycia pakietu akcji E. [tzn. spółki zależnej - dop. M.K.] [...] wyłączył realizację planu działania ustalonego przez spółkę-matkę, gdyż ten cel - sam w sobie - nie jest celem gospodarczym". Uwaga ta nie została szerzej wyjaśniona. Nawiązując do niej, można stwierdzić jedynie, że działania wskazane przez wnioskodawcę, takie jak rozdzielenie funkcji, zmniejszenie ryzyka gospodarczego działalności czy dywersyfikacja poziomu ryzyka, mieszczą się w pojęciu celu gospodarczego, które to pojęcie należy rozumieć szeroko ${ }^{4}$. Kwestią dyskusyjną może jednak pozostawać, czy w przypadku transakcji wewnątrzgrupowych istnienie celu gospodarczego powinno być analizowane z punktu widzenia konkretnego podatnika, czy też konieczne jest szersze spojrzenie - uwzględniające to, że działanie podjęte przez podatnika może być elementem realizacji szerszej strategii grupy kapitałowej. Kwestia ta, ze względu na jej złożoność, zostanie pozostawiona poza przedmiotem dalszych rozważań.

Szef KAS, rozstrzygając wniosek o wydanie opinii zabezpieczającej, odniósł się również do wskazanego przez podatnika motywu działania w postaci dążenia, poprzez sprzedaż akcji, do pozyskania środków finansowych. Szef KAS motyw ten uznał za nieistotny, wskazując, że wskazany cel mógł zostać osiągnięty w inny sposób. Organ wskazał, iż świadczy o tym fakt, że w analizowanej sprawie spółka matka zamiast podjętych działań w postaci dokapitalizowania podmiotu, który dokonał zakupu akcji od wnioskodawcy, mogła równie dobrze bezpośrednio dokapitalizować kupującego.

Logika wskazanego wywodu jest niewątpliwie przekonująca. Kontrowersyjny pozostaje jednak kontekst, w jakim został on przywołany. Istnienie alternatywnej drogi osiągnięcia przez podatnika określonego celu

${ }^{4}$ M. Kondej, Klauzula przeciwko unikaniu opodatkowania. Komentarz do przepisów materialnoprawnych, Poznań 2018, s. 74. 
gospodarczego nie świadczy bowiem o tym, że czynność została dokonana przede wszystkim w celu osiągnięcia korzyści podatkowej, a co najwyżej wskazuje na sztuczność sposobu działania podatnika. Kryteria głównego celu i sztuczności mają charakter rozdzielny. Weryfikacja, czy czynność została dokonana przede wszystkim w celu osiągnięcia korzyści podatkowej, wymagała, na gruncie stanu prawnego obowiązującego w 2017 r., zweryfikowania, czy pozostałe cele ekonomiczne lub gospodarcze czynności wskazane przez podatnika pozostają mało istotne. Fakt, że podatnik mógł uzyskać dokapitalizowanie w inny sposób, nie świadczy o tym, iż pozyskanie takiego dofinansowania nie było istotnym motywem dla decyzji o sprzedaży akcji. Stanowi jedynie mocny argument, że w istniejących okolicznościach taki sposób nie zostałby zastosowany przez podmiot dążący do uzyskania dofinansowania, a kierujący się celami innymi niż rozliczenie straty. Argument Szefa KAS może więc wskazywać na spełnienie warunku sztuczności, ale pozostaje to bez znaczenia dla oceny, czy głównym celem działania podatnika pozostawało osiągnięcie korzyści podatkowej.

Podkreślenia wymaga, że w stanie prawnym obowiązującym w 2017 r., inaczej niż obecnie, dla zastosowania klauzuli motywacja w postaci dążenia do osiągnięcia korzyści podatkowej spełniającej warunek sprzeczności musiała mieć charakter nadrzędny. Jeżeli więc podatnik wskazał istotny ekonomicznie motyw dla dokonania czynności, norma antyabuzywna nie znajdowała zastosowania. Dopiero od 2019 r. klauzulę można zastosować także w sytuacjach, w których osiągnięcie korzyści podatkowej było głównym lub jednym z głównych celów dokonania czynności ${ }^{5}$.

Powyższe nie oznacza oczywiście, że ocena Szefa KAS w zakresie tego, iż osiągnięcie korzyści podatkowej było głównym celem działania podatnika, jest nietrafna. Przywołane w informacji argumenty za takim stanowiskiem są jednak, w świetle poczynionych uwag, niewystarczające dla jej potwierdzenia.

\section{WARUNEK SPRZECZNOŚCI}

Drugim z warunków, który należy zbadać dla oceny, czy klauzula przeciwko unikaniu opodatkowania znajduje zastosowanie, jest warunek sprzeczności korzyści podatkowej z przedmiotem i celem przepisu ustawy podatkowej.

${ }^{5}$ Warto przy tym wskazać, że to, jak rozumieć wskazany warunek na gruncie znowelizowanych przepisów, też nie jest zupełnie jasne. 
Już na wstępie należy zwrócić uwagę, że warunek sprzeczności ma, w pewnym sensie, charakter nadrzędny wobec warunku sztuczności. Powyższe wynika z tego, iż zarówno na gruncie historycznej, jak i obecnie obowiązującej definicji sztuczności sztuczne jest takie działanie, które nie zostałoby zrealizowane w danej formie, gdyby podatnik przy wyborze formy tego działania kierował się motywacją inną niż osiągnięcie korzyści podatkowej spełniającej warunek sprzeczności. A contrario, jeżeli podatnik wybiera sposób działania, kierując się chęcią osiągnięcia korzyści podatkowej zgodnej z przedmiotem i celem ustawy podatkowej, to nie działa w sposób sztuczny. W tym kontekście należy zwrócić uwagę, że w rozstrzygnięciu Szefa KAS sprzeczność jest, w znacznym zakresie, wywodzona ze sztuczności działania podatnika. W szczególności organ najpierw ocenia sztuczność, by dopiero potem ocenić sprzeczność. Działanie to może być uznane za niepoprawne metodologicznie ${ }^{6}$. Przepisy jasno wskazują bowiem, że dokonanie oceny, czy mamy do czynienia z działaniem sztucznym, wymaga w pierwszej kolejności ustalenia, czy i w jakim zakresie doszło do powstania korzyści podatkowej spełniającej warunek sprzeczności.

Dla ustalenia, czy klauzula przeciwko unikaniu opodatkowania znajduje zastosowanie, należy więc się zastanowić, czy w analizowanym stanie faktycznym rozpoznanie przez podatnika straty na sprzedaży akcji pozostawało sprzeczne z celem ustawy podatkowej. Przepisem pozostającym osią sporu w analizowanej sprawie jest art. 16 ust. 1 pkt 8 ustawy o CIT. W brzmieniu obowiązującym w 2017 r. stanowił on, że nie uważa się za koszty uzyskania przychodów „wydatków na objęcie lub nabycie udziałów albo wkładów w spółdzielni, udziałów (akcji) oraz papierów wartościowych [...] wydatki takie są jednak kosztem uzyskania przychodu z odpłatnego zbycia tych udziałów (akcji) oraz papierów wartościowych, w tym z tytułu wykupu przez emitenta papierów wartościowych".

Szef KAS w wydanym rozstrzygnięciu zgodził się z wnioskodawcą, że rolą wskazanego przepisu jest przesunięcie w czasie możliwości potrącenia kosztów uzyskania przychodów związanych z nabyciem akcji do momentu ich zbycia. Jest to stanowisko trafne. Istotą art. 16 ust. 1 pkt 8 ustawy o CIT pozostaje odroczenie momentu rozpoznania kosztu do chwili, gdy podatnik osiąga związany z nim przychód. Mamy tu więc w istocie do czynienia

${ }^{6}$ W tym kontekście warto jednak zwrócić uwagę, że część autorów, w tym B. Kuźniacki, wskazuje, iż odwołanie się w przesłance sztuczności do sprzeczności jest nieracjonalne (B. Kuźniacki, Dekodowanie hipotezy GAAR: przesłanka sztuczności i jej istotny wpływ na przesłankę sprzeczności, cz. 2, „Przegląd Podatkowy” 2020, nr 7, s. 31). 
z pewnym doprecyzowaniem ogólnej zasady, że koszty bezpośrednie rozpoznaje się dopiero w momencie osiągnięcia związanego $\mathrm{z}$ nimi przychodu.

Szef KAS, jak się wydaje, nie miał też wątpliwości co do okoliczności towarzyszących powstaniu samej straty. Z przywołanej przez niego argumentacji stosunkowo jasno wynika, że nie widziałby on problemu w jej rozpoznaniu, gdyby transakcja sprzedaży została zrealizowana z niepowiązanym podmiotem trzecim.

Sprzeczność korzyści z przedmiotem i celem ustawy podatkowej organ podatkowy postrzega $\mathrm{w}$ tym, że wnioskodawca dokonał transakcji w ramach grupy kapitałowej. Argumentuje on, że zrealizowana transakcja, patrząc na nią z perspektywy grupy, nie zmieniła w żaden istotny sposób sytuacji prawnej, biznesowej i właścicielskiej spółki zależnej. Wskazuje, że w istocie doszło do przeniesienia spółki zależnej „z kieszeni do kieszeni”. W efekcie podnosi, że skoro grupa kapitałowa nie utraciła własności akcji, to $\mathrm{w}$ istocie nie możemy mówić o ich zbyciu.

W tym kontekście należy zwrócić uwagę, że przepisy ustawy o CIT nie dają podstaw do rozpatrywania skutków zdarzeń gospodarczych z perspektywy grupy kapitałowej jako pewnej całości. Wynik podatkowy ustala się, zgodnie z tymi przepisami, zasadniczo odrębnie dla każdej jednostki (podatnika). Wynik ten ma odzwierciedlać indywidualny rezultat zrealizowanych przez daną jednostkę operacji gospodarczych, w tym tych dokonanych z innymi spółkami z grupy kapitałowej, w skład której wchodzi podatnik. Jedyny przewidziany przepisami wyjątek przewidujący "grupową" kalkulację podatku dochodowego stanowią rozliczenia w ramach tzw. podatkowej grupy kapitałowej, $\mathrm{z}$ którą $\mathrm{w}$ analizowanej sprawie nie mamy do czynienia. W efekcie decydujące znaczenie przy ocenie podatkowych skutków transakcji winna mieć analiza ich skutków z punktu widzenia konkretnego podatnika, a nie grupy kapitałowej, do której on należy.

Przekładając powyższe na grunt analizowanej sprawy, należy stwierdzić, że z punktu widzenia wnioskodawcy doszło do faktycznego zbycia i przeniesienia własności akcji. Spółka sprzedająca utraciła bezpowrotnie ten składnik aktywów. W zamian otrzymała określone środki pieniężne. Otrzymana kwota nie ulegnie w przyszłości zmianie. Wnioskodawca, jako podatnik CIT, „zamknął” więc swoją inwestycję w akcje. W świetle celu art. 16 ust. 1 pkt 8 ustawy o CIT zasadne wydaje się zatem rozpoznanie, w rachunku podatkowym wnioskodawcy, wyniku na transakcji. Skoro celem art. 16 ust. 1 pkt 8 ustawy o CIT zidentyfikowanym przez Szefa KAS jest odroczenie momentu rozpoznania kosztu do chwili osiągnięcia przychodu, 
a przychód taki został osiągnięty przez wnioskodawcę w momencie zbycia akcji, zasadne pozostaje umożliwienie mu rozpoznania kosztu.

Fakt, że podatnik dokonał zbycia akcji spółce powiązanej nie powinien, w mojej ocenie, wpływać na jego prawo do rozpoznania kosztu. Potwierdzeniem tej tezy może być analiza sytuacji odwrotnej do tej, która stała się przedmiotem wniosku. Załóżmy hipotetycznie, że wartość akcji, które zakupił podatnik, nie spadła, ale wzrosła. Następnie podatnik, w ramach takiej samej transakcji jak analizowana w rozstrzygnięciu szefa KAS, dokonuje ich sprzedaży w ramach grupy kapitałowej. W takiej sytuacji trudno mieć wątpliwości, że opodatkowanie uzyskanego przez podatnika przychodu nie godzi w cel art. 16 ust. 1 pkt 8 ustawy o CIT. Jest tak, mimo że do transakcji również dochodzi w ramach grupy kapitałowej. Powstaje więc wątpliwość, czy cel przyświecający art. 16 ust. 1 pkt 8 ustawy o CIT uzasadnia to, by w wyniku podatkowym rozpoznawać dochód na transakcjach sprzedaży akcji w ramach grupy kapitałowej, ale pozbawiać podatnika prawa do rozpoznania straty na takich transakcjach. Trudno mi dostrzec argumenty, które przemawiałyby za takim zróżnicowaniem.

Istotną kwestią, która powinna być przeanalizowana w ramach badania zgodności rozpoznania korzyści z celem art. 16 ust. 1 pkt 8 ustawy o CIT, jest też to, kiedy, jeżeli nie w momencie sprzedaży akcji w ramach grupy kapitałowej, podatnikowi miałoby przysługiwać prawo rozpoznania wyniku na takiej transakcji. Szef KAS argumentuje, że prawo do rozpoznania straty powinno powstawać dopiero w momencie zbycia akcji mającego ekonomiczne znaczenie. Nie dostrzegam jednak w ustawie o CIT czy Ordynacji podatkowej przepisów, które dawałyby wnioskodawcy prawo rozpoznania straty w momencie innym niż moment ich faktycznego zbycia.

Warto zwrócić uwagę, że przyznanie $\mathrm{w}$ analizowanej sprawie podatnikowi prawa do rozpoznania straty pozostaje zgodne $\mathrm{z}$ celem ustawy podatkowej jako pewnej całości. Jak wskazuje sama nazwa podatku dochodowego od osób prawnych, obciąża on dochód podatnika. Punktem wyjścia przy ustalaniu kwoty zobowiązania podatkowego jest $z$ tego powodu różnica pomiędzy uzyskanymi przez podatnika przysporzeniami a wydatkami, które poniósł on w celu ich osiągnięcia ${ }^{7}$. W analizowanej sprawie

7 Zob. bardziej szczegółowo: H. Filipczyk, „Sprzeczność z przedmiotem lub celem ustawy podatkowej lub jej przepisu” jako klauzulowa przesłanka unikania opodatkowania, „Przegląd Podatkowy” 2020, nr 3, s. 30-31; eadem, Refleksje o przedmiocie podatku dochodowego, „Kwartalnik Prawa Podatkowego” 2015, nr 2, s. 39-55; M. Kondej, Jeszcze o koszcie jako wydatku związanym z przychodami. Racjonalność działania podatnika 
rozpoznanie wyniku podatkowego na sprzedaży prowadzi do uwzględnienia w rachunku podatkowym podatnika tak rozumianego, ekonomicznego wyniku transakcji, co odzwierciedla cel ustawy o CIT.

W efekcie, moim zdaniem, rozpoznanie faktycznie poniesionej ekonomicznej straty na sprzedaży akcji w momencie definitywnego wyzbycia się przez spółkę tych akcji nie pozostaje w sprzeczności z przedmiotem i celem art. 16 ust. 1 pkt 8 ustawy o CIT. Rolą tego przepisu jest bowiem odroczenie momentu rozpoznania kosztu do chwili zakończenia inwestycji $\mathrm{w}$ dany instrument. $\mathrm{W}$ analizowanej sprawie podatnik inwestycje $\mathrm{w}$ akcje spółki zależnej zakończył, osiągnął przychód z tego tytułu, powinien mieć więc prawo do rozpoznania korespondującego $\mathrm{z}$ tym przychodem kosztu.

\section{WARUNEK SPRZECZNOŚCI A SZTUCZNOŚĆ}

Szef KAS wskazuje, że sprzeczność korzyści podatkowej wynika ze sztuczności działania podatnika. Jego argumentacja sprowadza się do tego, iż racjonalnie działający podmiot, który nie kierowałby się chęcią rozliczenia straty, nie dokonałby takiej transakcji.

Odnosząc się do powyższego, należy stwierdzić, że podatnik na gruncie przepisów klauzuli przeciwko unikaniu opodatkowania ma prawo wyboru optymalnej podatkowo formy realizacji swoich działań gospodarczych ${ }^{8}$. Granicę tego uprawnienia stanowi zakaz dokonywania działań sztucznych, prowadzących do uzyskania korzyści, które są sprzeczne z celem przepisów ustawy ${ }^{9}$.

Przesłanki sprzeczności i sztuczności niewątpliwie pozostają ze sobą powiązane ${ }^{10}$. Istotą sprzeczności korzyści podatkowej $\mathrm{z}$ przedmiotem przepisu ustawy podatkowej pozostaje to, że na skutek dokonanych przez

jako przesłanka rozpoznania kosztu podatkowego, „Kwartalnik Prawa Podatkowego” 2018, nr 4, s. 95-97.

8 Zob. m.in. Uchwała Nr 1 Rady do Spraw Przeciwdziałania Unikaniu Opodatkowania z dnia 2 marca 2020 r., pkt 36; wyrok Naczelnego Sądu Administracyjnego (NSA) z dnia 11 stycznia 2019 r., sygn. II FSK 3242/18 (wszystkie przytoczone wyroki są dostępne na: orzeczenia.nsa.gov.pl).

9 Wyrok NSA z dnia 8 lipca 2019 r., sygn. II FSK 135/19.

10 Tak też m.in.: H. Filipczyk, „Sprzeczność z przedmiotem lub celem ustawy podatkowej lub jej przepisu”..., s. 34; B. Kuźniacki, Dekodowanie hipotezy GAAR..., s. 28; Uchwała Nr 1 Rady do Spraw Przeciwdziałania Unikaniu Opodatkowania z dnia 2 marca 2020 r., pkt 57; wyrok NSA z dnia 11 stycznia 2019 r., sygn. II FSK 3242/18; wyrok NSA z dnia 8 lipca 2019 r., sygn. II FSK 135/19. 
podatnika czynności zastosowanie znajduje nieadekwatny do danego stanu faktycznego przepis, tj. przepis, który w świetle jego celu nie powinien dotyczyć transakcji danego typu ${ }^{11}$. Doprowadzenie do zastosowania „nieadekwatnego” przepisu możliwe pozostaje przez dokonanie czynności sztucznych, a więc, w pewnym uproszczeniu, czynności niemających uzasadnienia gospodarczego - takich, których nie dokonałby racjonalny podatnik. Związek pomiędzy przesłankami sprzeczności i sztuczności wyraża się zatem w tym, że czynności sztuczne mogą prowadzić do sprzeczności. Nawet jednak gdy podatnik realizuje określone działania wyłącznie w celu osiągnięcia korzyści podatkowej, nie oznacza to, że są to działania sprzeczne z przedmiotem czy celem ustawy ${ }^{12}$. Dobrą ilustracją tego wydaje się analizowana sprawa.

Jak już wskazywano, ogólnym założeniem ustawy o podatku dochodowym od osób prawnych pozostaje opodatkowanie faktycznego dochodu podatnika. W efekcie, jeżeli podatnik dokonuje, tak jak w sprawie rozstrzyganej przez Szefa KAS, faktycznej sprzedaży składnika aktywów ze stratą i wyzbywa się definitywnie jego własności, rozpoznanie straty (różnicy pomiędzy otrzymaną ceną sprzedaży a wydatkami na nabycie aktywów) nie narusza celu ustawy. Brak też w analizowanym przypadku sprzeczności takiego działania z którymkolwiek z przepisów szczególnych, które potencjalnie mogłyby wprowadzać wyjątki od ogólnej zasady, że przedmiotem opodatkowania jest dochód. O nadużyciu, w przypadku sprzedaży aktywów ze stratą, moglibyśmy mówić dopiero przy przekroczeniu określonego

${ }^{11}$ Podobnie argumentuje Szef KAS w części opinii zabezpieczających, argumentując: „Sprzeczności korzyści podatkowej z przedmiotem lub celem ustawy podatkowej lub jej przepisu należy dopatrywać się w takich sytuacjach, w których podatnik poprzez sztuczne działania doprowadził do zastosowania lub niezastosowania norm skutkujących efektem podatkowym nieadekwatnym do charakteru realizowanych działań gospodarczych. Przy czym adekwatność skutków podatkowych realizowanych działań należałoby oceniać przez pryzmat sztucznie zastosowanych lub ominiętych przepisów prawa, jak i pod kątem założeń konstrukcyjnych danego podatku, a także rozbieżności pomiędzy ekonomicznymi i podatkowymi skutkami działań w danych okolicznościach" - zob. m.in. Informacje Szefa KAS o wydaniu / odmowie wydania opinii zabezpieczającej: z 3 sierpnia 2020 r. (DKP3.8011.8.2020), z 22 czerwca 2020 r. (DKP2.8011.19.2019), z 9 czerwca 2020 r. (DKP3.8011.17.2019), z 30 kwietnia 2020 r. (DKP2.8011.20.2019).

12 Tak też m.in.: H. Filipczyk, „Sprzeczność z przedmiotem lub celem ustawy podatkowej lub jej przepisu”..., s. 33; B. Kuźniacki, Dekodowanie hipotezy GAAR..., s. 29; M. Kondej, T. Cebula, Dlaczego przesłanki „sprzeczności korzyści podatkowej z przedmiotem lub celem ustawy podatkowej lub jej przepisu” nie należy nazywać „samospetniająca się”, „Monitor Podatkowy" 2020, nr 10, Legalis/el. 
poziomu sztuczności, np. gdyby wyzbycie się władztwa nad składnikiem majątku miało charakter pozorny, w potocznym rozumieniu tego pojęcia ${ }^{13}$, np. umowa przewidywałaby prawo jego odkupu, a równocześnie umożliwiała spółce dalszą kontrolę nad spółką zależną i czerpanie profitów z jej działalności.

Szef KAS w odmowie wydania opinii argumentuje, że bardziej adekwatnym sposobem realizacji celu gospodarczego spółki niż przeprowadzona sprzedaż akcji byłby podział przez wydzielenie. Wywodząc sprzeczność ze sztuczności, w istocie argumentuje on, że podatnik, dokonując sprzedaży, a nie podziału przez wydzielenie, doprowadził do zastosowania nieadekwatnego przepisu prawa podatkowego. W takim ujęciu korzyść, jak się wydaje, miałaby pozostawać sprzeczna z przedmiotem przepisu przewidującego neutralność podatkową podziału przez wydzielenie, który podatnik „sztucznie ominął”.

W tym kontekście należy zwrócić jednak uwagę, że klauzula przeciwko unikaniu opodatkowania nie nałożyła na podatnika obowiązku realizacji czynności gospodarczych w taki sposób, który wiąże się dla niego z najwyższym obciążeniem podatkowym. Okoliczność ta znajduje potwierdzenie $\mathrm{w}$ orzecznictwie NSA i opiniach rady ds. unikania opodatkowania ${ }^{14}$. Jeżeli podatnik ma możliwość osiągnięcia określonego celu gospodarczego na wiele różnych sposobów, to $z$ faktu, że dokonał wyboru tego, który wiąże się z najmniejszym obciążeniem podatkowym, nie wynika jeszcze sprzeczność osiągniętej w ten sposób korzyści z przepisami, które nie znalazły, na skutek dokonanego wyboru, zastosowania ${ }^{15}$. Przykładowo jest dość oczywiste, że gdy podatnik emituje obligacje, żeby nie płacić PCC od pożyczki, to nie oznacza to, że brak zapłaty PCC pozostaje sprzeczny z przedmiotem i/lub celem ustawy o PCC.

Tam, gdzie przepisy przewidują odmienne zasady opodatkowania różnych czynności, które prowadzą do osiągnięcia zbliżonego celu gospodarczego, fakt,

13 Działania mające na celu optymalizację podatkową nie stanowią czynności pozornych w sensie prawnym, co szczegółowo wywodzę w innej publikacji: M. Kondej, Granice optymalizacji podatkowej przed wejściem w życie klauzuli przeciwko unikaniu opodatkowania, Poznań 2017, s. 243-263.

14 Uchwała Nr 1 Rady do Spraw Przeciwdziałania Unikaniu Opodatkowania z dnia 2 marca 2020 r., pkt 36.

15 Podobnie: A. Werner, Istota unikania opodatkowania, [w:] Klauzula przeciwko unikaniu opodatkowania, red. D. Gajewski, LEX/el.; A. Ladziński, Zmiany w ogólnej klauzuli przeciwko unikaniu opodatkowania - powrót do przeszłości, „Przegląd Podatkowy” 2019, nr 1, s. 25. 
że podatnik decyduje się na realizację czynności korzystniejszej podatkowo, nie prowadzi do sprzeczności. Decyzją ustawodawcy pozostaje to, że sprzedaż i podział przez wydzielenie mają odmienne konsekwencje podatkowe. $\mathrm{W}$ tym przypadku zastosowanie do działania podatnika zależnie od wybranej przez niego formy transakcji właściwych przepisów pozostaje zgodne, a nie sprzeczne, $\mathrm{z}$ ich przedmiotem i celem ${ }^{16}$.

Sprzeczność na skutek sztuczności wystąpi tylko wtedy, gdy zastosowanie znajdą przepisy niewłaściwe, jeśli wziąć pod uwagę m.in. treść ekonomiczną transakcji. Dla stwierdzenia sprzeczności występujące $\mathrm{w}$ transakcji elementy sztuczne muszą być więc tego rodzaju, by wskazywać na to, że podatnik w istocie dokonał innej transakcji, niżby to wynikało z nadanej jego czynnościom formy prawnej, oraz że ta „inna transakcja” powinna być odmiennie opodatkowana ${ }^{17}$. Gdy podatnik wybiera formę transakcji odpowiadającą jej treści ekonomicznej i stosuje właściwe do tej formy transakcji przepisy podatkowe, przesłanka sprzeczności nie jest spełniona.

\section{WARUNEK SZTUCZNOŚCI}

Brak sprzeczności korzyści podatkowej z przedmiotem i celem ustawy podatkowej, jak już wcześniej wskazywałem, na gruncie literalnego brzmienia polskich przepisów oznacza brak możliwości uznania działania podatnika za sztuczne. Mimo to przesłankę sztuczności warto odrębnie skomentować.

Przypomnijmy, że sztuczny jest taki sposób działania, który w istniejących okolicznościach nie zostałby zastosowany przez podmiot działający rozsądnie i kierujący się zgodnymi z prawem celami innymi niż osiągnięcie korzyści podatkowej sprzecznej z przedmiotem i celem przepisu ustawy podatkowej. W dalszych analizach będę pomijał powiązanie pomiędzy warunkami sztuczności i sprzeczności, uznając, że każdy sposób działania motywowany podatkowo jest sztuczny niezależnie od tego, czy osiągnięta korzyść podatkowa jest, czy też nie jest sprzeczna z celem ustawy podatkowej.

16 GAAR jest normą antyabuzywną. Jego stosowanie nie może prowadzić do podważenia istoty przepisów prawa podatkowego (zob. B. Kuźniacki, The Polish GAAR is Just a GAAR! Why the Head of the National Revenue Administration Thinks Differently?, Kluwer International Tax Blog, http://kluwertaxblog.com/2020/08/04/the-polish-gaaris-just-a-gaar-why-the-head-of-the-national-revenue-administration-thinks-differently/, dostęp: 14.08.2020).

17 Zob. m.in. wyrok NSA z dnia 8 lipca 2019 r., sygn. II FSK 135/19. 
W glosowanej sprawie sztuczność można oceniać na dwóch płaszczyznach. Po pierwsze, można się zastanawiać, czy podatnik, gdyby nie korzyść podatkowa, w ogóle zrealizowałby jakąkolwiek transakcję. Dane zawarte $\mathrm{w}$ informacji o odmowie wydania opinii zabezpieczającej nie pozwalają jednoznacznie ocenić tej kwestii. Jeżeli podatnik na skutek sprzedaży akcji uzyskał środki finansowe, które faktycznie były mu niezbędne do regulowania zobowiązań, z sytuacją tą niewątpliwie nie mielibyśmy do czynienia.

W tym kontekście podkreślenia wymaga to, że w stanie prawnym obowiązującym w 2017 r. tak długo, jak podatnik wskazał choćby nieistotne cele podatkowe czynności, organ podatkowy nie był uprawniony do całkowitego pominięcia skutków podatkowych transakcji. Możliwość pominięcia skutków podatkowych transakcji przewidywał bowiem wówczas jedynie art. 119a $\$ 5$ Ordynacji podatkowej, który znajdował zastosowanie wyłącznie w przypadku, gdy osiągnięcie korzyści podatkowej było jedynym celem czynności. Dopiero z dniem 1 stycznia 2019 r. w art. 119a $\$ 3$ wskazano, że czynność odpowiednia może polegać także na zaniechaniu działania, co literalnie interpretując przepis, pozwala pomijać organom przy wymiarze podatku nawet te czynności podatnika, które miały określone, acz nieistotne, uzasadnienie gospodarcze.

Drugim aspektem oceny sztuczności jest konieczność weryfikacji, czy rozsądnie działający podatnik w celu realizacji określonych celów nie dokonałby transakcji innej niż ta, która faktycznie została zrealizowana. W tym zakresie Szef KAS argumentuje, że właściwsze od nabycia przez spółkę matkę nowej spółki, wniesienia do niej wkładu i jej dofinansowania, a następnie nabycia przez taką spółkę akcji od wnioskodawcy, byłoby przeprowadzenie przez wnioskodawcę podziału przez wydzielenie i przeniesienie akcji, wraz z pracownikami, do nowo utworzonej spółki.

Nie przekonuje mnie ten argument. Po pierwsze, proces podziału przez wydzielenie wydaje się wielokrotnie trudniejszy i bardziej czasochłonny niż proces nabycia, dokapitalizowania spółki, a następnie zawarcia umowy sprzedaży. Po drugie, podział przez wydzielenie nie zapewniłby realizacji deklarowanego przez wnioskodawcę celu w postaci uzyskania środków finansowych na spłatę jego zobowiązań.

Sztuczność zrealizowanej transakcji jest więc wątpliwa, nawet pomijając to, że na gruncie definicyjnym sztuczność występuje tylko wtedy, gdy zaistnieje sprzeczność. 
W ujęciu jednostkowym poczynione w niniejszej glosie spostrzeżenia pozwalają podać w wątpliwość prawidłowość rozstrzygnięcia Szefa KAS odnośnie do odmowy wydania opinii zabezpieczającej. Bazując na danych zawartych w opublikowanej informacji, można się zastanawiać, czy rzeczywiście sprzedaż akcji spełniała którykolwiek z trzech omówionych warunków zastosowania klauzuli przeciwko unikaniu opodatkowania ${ }^{18}$.

W szerszej perspektywie poczynione przemyślenia wskazują na to, jak ważne pozostaje odrębne analizowanie, czy spełniona pozostaje każda $\mathrm{z}$ przesłanek zastosowania klauzuli ${ }^{19}$. Mimo że pomiędzy wskazanymi przesłankami istnieją liczne związki, a ich precyzyjne rozgraniczenie dla potrzeb teoretycznych jest trudne, praktyka pokazuje, że każda z nich powinna być analizowana oddzielnie.

Powyższa uwaga dotyczy w szczególności przesłanek sprzeczności i sztuczności. Przesłanka sprzeczności nie jest bowiem przesłanką samospełniającą się, gdy wykaże się sztucznośćc ${ }^{20}$. W szczególności fakt, że podatnik, podejmując decyzję, kieruje się chęcią uzyskania korzyści podatkowej, nie pozwala na automatyczne przyjęcie, iż korzyść ta jest sprzeczna z przedmiotem i celem ustawy podatkowej, gdyż ustawa przewiduje odmienne zasady opodatkowania różnych stanów faktycznych. Tak długo, jak działanie podatnika sprowadza się do wyboru optymalnego podatkowo instrumentu służącego realizacji określonego celu gospodarczego, brak podstaw do stwierdzenia, że jest ono sprzeczne z przedmiotem i celem przepisów, które nie znajdują, na skutek dokonania tego wyboru, zastosowania ${ }^{21}$.

${ }^{18}$ Należy przy tym zastrzec, iż stosownie do art. 119zda $\$ 2$ Ordynacji podatkowej wydana informacja stanowi jedynie zwięzły opis poddanej pod opinię czynności oraz wyjaśnienie powodów podjętego rozstrzygnięcia. Z tego względu autor swoją ocenę opiera tylko na analizie treści opublikowanej informacji.

19 Teza ta właściwie nie budzi wątpliwości w doktrynie, zob. np. J. Jankowski, Konstytucyjność klauzuli ogólnej przeciwko unikaniu opodatkowania, „Monitor Podatkowy” 2020, nr 5, s. 29; H. Filipczyk, „Sprzeczność z przedmiotem lub celem ustawy podatkowej lub jej przepisu”..., s. 33-34; M. Guzek, M. Stefaniuk, Klauzula przeciwko unikaniu opodatkowania. Komentarz praktyczny, Warszawa 2018, s. 40.

20 Zob. też M. Kondej, T. Cebula, Dlaczego przesłanki...

${ }^{21}$ Podobnie uważa M. Stefaniak, który wskazuje, że „sposób działania nie może być uznany za sztuczny, jeżeli przyjęta konstrukcja osiągnięcia tego celu [celu gospodarczego] nie cechuje się nadmierną zawiłością i brakiem celu gospodarczego" (M. Stefaniak, Cel dokonania czynności oraz sztuczny sposób działania jako odrębne przesłanki stosowania klauzuli przeciwko unikaniu opodatkowania, „Przegląd Podatkowy” 2020, nr 5, s. 24). 
Klauzula przeciwko unikaniu opodatkowania, zarówno w historycznym, jak i obecnym brzmieniu, nie zabrania podatnikowi realizowania transakcji tylko po to, by osiągnąć korzyść podatkową, tak długo, jak osiągnięcie tej korzyści nie narusza celu przepisów. Jak bowiem słusznie wskazuje Naczelny Sąd Administracyjny: „celem klauzuli przeciwko unikaniu opodatkowania nie jest [...] odebranie podatnikowi możliwości legalnego zminimalizowania wysokości płaconych przez niego podatków (optymalizacja podatkowa), ale ograniczenie możliwości zmniejszenia obciążeń podatkowych w przypadku, gdy podatnik będzie podejmował w tym celu działania sztuczne, nieznajdujące uzasadnienia ekonomicznego, a jednocześnie [podkreśl. M.K.] sprzeczne z celem i przedmiotem ustawy podatkowej"22. Podatnik, który poniósł ekonomiczną stratę na inwestycji, może więc zrealizować ją dla celów podatkowych, sprzedając posiadane akcje.

\section{BIBLIOGRAFIA}

Cebula T., Kondej M., Dlaczego przesłanki „sprzeczności korzyści podatkowej z przedmiotem lub celem ustawy podatkowej lub jej przepisu” nie należy nazywać „samospetniajaca się", „Monitor Podatkowy” 2020, nr 10, Legalis/el.

Filipczyk H., Refleksje o przedmiocie podatku dochodowego, „Kwartalnik Prawa Podatkowego" 2015, nr 2.

Filipczyk H., „Sprzeczność z przedmiotem lub celem ustawy podatkowej lub jej przepisu” jako klauzulowa przesłanka unikania opodatkowania, „Przegląd Podatkowy” 2020, nr 3.

Guzek M., Stefaniuk M., Klauzula przeciwko unikaniu opodatkowania. Komentarz praktyczny, Warszawa 2018.

Jankowski J., Konstytucyjność klauzuli ogólnej przeciwko unikaniu opodatkowania, „Monitor Podatkowy" 2020, nr 5.

Kondej M., Granice optymalizacji podatkowej przed wejściem w życie klauzuli przeciwko unikaniu opodatkowania, Poznań 2017.

Kondej M., Jeszcze o koszcie jako wydatku związanym z przychodami. Racjonalność dziatania podatnika jako przesłanka rozpoznania kosztu podatkowego, „Kwartalnik Prawa Podatkowego" 2018, nr 4.

Kondej M., Klauzula przeciwko unikaniu opodatkowania. Komentarz do przepisów materialnoprawnych, Poznań 2018.

Kondej M., Zmiany w klauzuli ogólnej przeciwko unikaniu opodatkowania wchodzace wżycie w 2019 r., „Praktyka Podatkowa” 2018, nr 1.

Kuźniacki B., Dekodowanie hipotezy GAAR: przesłanka sztuczności i jej istotny wplyw na przesłankę sprzeczności, cz. 2, „Przegląd Podatkowy” 2020, nr 7.

22 Wyrok NSA z dnia 8 lipca 2019 r., sygn. II FSK 135/19. 
Kuźniacki B., The Polish GAAR is Just a GAAR! Why the Head of the National Revenue Administration Thinks Differently?, Kluwer International Tax Blog, http://kluwertaxblog. com/2020/08/04/the-polish-gaar-is-just-a-gaar-why-the-head-of-the-nationalrevenue-administration-thinks-differently/ (dostęp: 14.08.2020).

Ladziński A., Zmiany w ogólnej klauzuli przeciwko unikaniu opodatkowania - powrót do przeszłości, „Przegląd Podatkowy” 2019, nr 1.

Stefaniak M., Cel dokonania czynności oraz sztuczny sposób działania jako odrębne przesłanki stosowania klauzuli przeciwko unikaniu opodatkowania, „Przegląd Podatkowy" 2020, nr 5.

Werner A., Istota unikania opodatkowania, [w:] Klauzula przeciwko unikaniu opodatkowania, red. D. Gajewski, Warszawa 2018, LEX/el.

\section{General ANTI-AVOIDANCE RUle (GAAR) DOES NOT MEAN PROHIBITION of tAX OPTIMIZATION. AdVERSE gloss to DECISION REFUSING ISSUING PROTECTIVE OPINION OF 28 MAY 2020 (DKP3.8011.8.2019)}

Summary. On 28 May 2020 the Head of Polish Revenue Administration refused to issue protective opinion under general anti-avoidance rule (GAAR) regarding taxpayer right to recognize taxable loss on sale of shares in a subsidiary. The transaction took part between related parties. The loss was result of a significant drop in market value of the subsidiary shares due to business fail of this entity. The tax authority argued that, in given circumstances, recognition of loss on sale remains contrary to the object and purpose of the tax law due to the fact that intra-group transactions should not be utilized to manipulate taxable revenue. In the article the author challenges correctness of such argumentation. He claims that recognition of actual economical loss, as a result of sale of shares to related party, remains in line with the aim and spirit of the tax law.

Keywords: general anti-avoidance rule, GAAR, Article 119 of the tax ordinance, tax advantage that defeats the object or purpose of the law, non-genuine arrangement, related parties 